\title{
MEDIA LITERACY EDUCATION FOR HIGH SCHOOL STUDENTS: ITS NECESSITY AND CHALLENGE
}

\author{
Trufi Murdiani, Muhtarom, Dwi Rohmadi Mustofa, Moh. Masrur \\ Business Digital Study Program, Business and Economic Faculty, IIB Darmajaya, \\ Sekolah Tinggi Ilmu Tarbiyah Pringsewu, \\ e-mail: missmurdian1@gmail.com, muhtarom29@gmail.com, \\ dwirohmadimustofa91@gmail.com, masrurpring1000@gmail.com
}

\begin{abstract}
Media of all kinds, across all platforms, have become so integrated into modern life. An effort is needed to control the negative influences of media. Students can access media easily and they need filter to get the good source of information from media. This goal can be reached with media literacy education. This research finds that in 12 years, mainstream and new media in Lampung grows rapidly. Beside national media that distribute in Lampung, there are also local/provincial media as well as local and national TV, radio stations, e-news and social medias. High schools in Lampung Province especially Bandarlampung have already applied media literacy lesson as a part of Bahasa Indonesia (Indonesian) course and given to students at the last semester. In SMAN 1 Bandarlampung the media literacy focuses on information and communication technology (ICT). This in one chapter of Bahasa Indonesia course under a title Media Literacy, but only focuses on ICT. The method in this study is interview the school civities namely teacher and students. The research recommendation is that in Bandarlampung the application of Media Literacy learning can be hampered if there is no synergy between the school and Dinas Pendidikan.
\end{abstract}

Keywords: information, news, languange.

\begin{abstract}
Abstrak
Semua jenis media massa di berbagai platform, telah terintegrasi dalam kehidupan modern. Diperlukan upaya untuk mengendalikan pengaruh negatif media karena pelajar mudah mengakses media sehingga perlu filter untuk mendapatkan sumber informasi yang baik dari media. Tujuan penerlitian ini untuk pencapaian pendidikan literasi media. Penelitian ini menemukan bahwa dalam 12 tahun, media massa tumbuh pesat di Lampung. Selain media nasional yang beredar di Lampung, ada juga media lokal tingkat provinsi serta TV lokal dan nasional, stasiun radio, e-news dan media sosial. Sekolah menengah di Provinsi Lampung, khususnya Bandarlampung telah menerapkan pelajaran literasi media sebagai bagian dari matapelajaran Bahasa Indonesia (Indonesia) dan diberikan kepada siswa pada semester terakhir. Di SMAN 1 Bandarlampung, literasi media fokus pada teknologi informasi dan komunikasi (TIK). Tepatnya, pada bab tentang Literasi Media di matapelajaran Bahasa Indonesia. Metode yang digunakan dalam penelitian ini adalah wawancara dengan pihak sekolah yaitu guru dan siswa. Rekomendasi penelitian ini adalah bahwa di Bandarlampung penerapan pembelajaran Literasi Media dapat terhambat jika tidak ada sinergi antara sekolah dan Dinas Pendidikan.
\end{abstract}

Kata-kata kunci: informasi, berita, bahasa. 


\section{A. INTRODUCTION}

Teenagers in Bandar Lampung City are able to watch television for 3.5 to 5 hours a day (Kompas Daily, February 17, 2012). Ideally a teenager should only watch two hours of television at most a day. Teenagers do not just watch the show that is intended for them but also the impressions that have not been appropriate for them to see. This condition occurs, mostly without close supervision from their parents. The selection of media as a source of information by young people needs wisdom to avoid mistakes in obtaining information and entertainment through media that have not been feasible for them. One of its medium is television, both of the television stations and the as well as the content of the shows.

Data on young people who view television indicate that the number of hours watching beyond the ideal watching hours. The figures of 35 hours per week equates to 1,820 hours per year, whereas the study time for young people in worldwide according to the United Nations Education and Culture Organization (UNESCO) does not exceed 1,000 hours per year. Comparing the number of watching television hours by the number study hours at school, it is feared that the formation for process of thinking, character, and behavior will be formed through television.

In the last 12 year, mainstream media situation in Lampung growths in rapid condition. Beside national media that distribute in Lampung, there are also local/provincial media as well as media, mostly newspapers in regency scale that distribute in Lampung. The national media that distribute in Lampung Province are usually from big media company group. For daily newspaper, there are numbers of media that are read every day by people in Lampung, either as customer readers or retail newspaper buyers. Those national newspapers such as Kompas, Republika, Media Indonesia, Rakyat Merdeka and The Jakarta Post, also some weekly tabloids and monthly magazines.

While the local mainstream media are generally divided as daily newspapers and weekly newspapers and/or tabloids. The local daily newspapers are published both by big national media company groups, like Radar Lampung, Lampung Post, Tribun Lampung, Rakyat Lampung. Then, there are still many daily newspapers published by local investors such as Lampung Ekspres and Bandar Lampung News. Some local TV stations also growth well. The rapid increasing growth of mainstream media is also happened for radio station.

In addition to mainstream media, the new media with internet base technology also brings the more interested information to people in Bandarlampung City in many formats such us blogs, YouTube, Twitter, social networking sites, live video streaming of news report and shows. In the last five years, internet has allowing anyone in Bandarlampung City with access to the information with various contents.

While in SMAN 1 Bandarlampung, the course of media literacy is only one chapter under Indonesian course with the lack of learning time to students as some students said in the interview session.

\section{B. OBJECTIVES OF THE STUDY:}

This project aims to find out the kind of media literacy course being taught in SMAN 1 Bandarlampung and to compare it with the UNESCO-mandated media literacy course.

The specific objectives are:

1. To identify the features of the existing media literacy program in Sekolah Menengah Atas Negeri (SMAN) or State High School 1 Bandarlampung,

2. To examine how Bahasa Indonesia teacher teaches the media literacy course.

3. To find out what students learn from the course.

And the significance is to build the discussion on new perspective of public issues in the knowledge of journalism field as well as to the practice of education, on how application of media literacy education can enhance young people's awareness and wisdom.

\section{METHODS}

The methodology that used in this research:

1. The observation.

Observation was taken in January 2020 in the class of 12-IPA-2 (one of the third class/last level of second science class) in SMAN 1 Bandarlampung ( $1^{\text {st }}$ State High School in Bandarlampung City) as the object of research on Media Literacy Learning. This class has 40 students with one teacher per course. 
The observation has done that date when the chapter of media literacy held for the third level of students in SMAN 1 Bandarlampung.

2. Interviews

It focused with three students who take Media Literacy Lesson in Bahasa Indonesia Course/Class. They are Vanny Unjungan Sari as the success student in this course, Nindya Fitrika as one of the "unsucceess" student, and Viola, in the middle level of student.

The interview was also conducted with teacher, head of SMAN 1 Bandarlampung City as well as Education Institution/Dinas Pendidikan in Bandarlampung City.

2.1. Interview with students: a. Vanny Unjungan Sari; 16 years, the success student, female, Bandarlampung citizen.

b. Nindya Fitrika; 17 years old, not success student, female, Bandarlampung citizen.

c. Viola; 17 years old, female, the middle students, Bandarlampung citizen.

2.2. Interview with teachers:

a. Mr. Budi Susilo, Bahasa Indonesia/ICT teacher.

b. Mr. Baduzzaman, head of SMAN 1 Bandarlampung.

2.3. Interview with Education Institution Officer in Bandarlampung City.

\section{FRAMEWORK}

News and information are now accessible at any time by people in Lampung including the youths. Media of all kinds, across all platforms, have become so integrated into modern life that their presence and influence are not always noticeable. UNESCO promotes the concept of knowledge societies that is based on four major principles: equal access to quality education for all; universal access to information; cultural and linguistic diversity; and freedom of expression. Literacy has traditionally been described as the ability to read and write, with arithmetical literacy often added to the mix.

The UNESCO Expert Group meeting on Literacy Assessment in 2003 defined literacy in these terms as it is mentioned in Towards Media and Information Literacy Indicators (2011, p. 9) as:

Literacy is the ability to identify, understand, interpret, create, communicate and compute using printed and written materials associated with varying contexts. Literacy involves a continuum of learning in enabling individuals to achieve his or her goals, develop his or her knowledge and potential and participate fully in community and wider society.

And today, literate individuals need to have a critical comprehension of messages, including 'media texts.' (p.10)

As the authors of the Global Literacy Challenge (UNESCO, 2008b) have noted in Towards Media and Information Literacy Indicators (2011, p. 9):

There is no single notion of literacy as a skill which people possess or not, but multiple literacy. We all engage in both oral and written practices and in learning new literacy at different stages of our lives, for example, the literacy demands of digital technologies. The concept of 'situated literacy' draws attention to how the social, cultural and political context shapes the ways in which people acquire and use literacy.

The term media literacy is, in turn, generally conceptualized as the knowledge and skills individuals need to analyze, evaluate, or produce media messages. (p.15).

The definition of media literacy, according to UNESCO is generally as the ability of citizens to access the media, to understand and to critically evaluate different aspects of the media and media contents and to create communications in a variety of contexts. (Towards Media and Information Literacy Indicators, 2011)

UNESCO also sets media literacy as: To emphasize the ability of citizen to understand, evaluate and use media as a leading 
purveyor and processor, if not producer, of information. It is appropriate, therefore, that in the process of elaboration of the MIL indicators, UNESCO considers information literacy and media literacy together as Information Literacy-Media Literacy or Media Information Literacy (MIL).

According to UNESCO's Media and Information Literacy Curriculum for Teachers, multiple - and related- literacy are included in the concept of media and information literacy (MIL). They are:

- Computer Literacy

- Digital Literacy

- Freedom of Expression

- Freedom of Information Literacy

- Information Literacy

- Internet Literacy

- Library Literacy

- Media Literacy

- News Literacy

Media literacy curriculum for teachers identifies key elements/outcomes as:

- Understand the role and functions
of media in democratic societies,
- Understand the conditions under
which media can fulfill their functions,
- Critically evaluate media content
in the light of media functions,
- $\quad$ Engage with media for self-
expression and democratic participation,
- Skills needed to produce user-
generated content,
- Use of ICTs in this process.

\section{RESULTS AND DISCUSSION}

The course of media literacy is very useful. That is what Vanny Unjungan Sari, a student of SMAN 1 Bandarlampung said about the Media Literacy course she took in the last semester of the last level or grade in SMAN 1 Bandarlampung.

She added she takes benefits from this course. She can use internet and new media to raise my knowledge. In that school, students could access internet not only when they took media literacy or Bahasa Indonesia course but also for other courses and even at the break time. There are allowed to access wifi and have their own account on social media like Facebook, Twitter, and personal blog as well as school website. So, anytime in the school and out of the school times, thare able to access internet by laptop and/or cell phone but to do Facebook and Twitter, usually only during the break time.

What Vanny has said about media literacy course is actually about Information and Communications Technology (ICT). This is as the observation in her class, the last class or third level of Science Class in SMAN 1 Bandarlampung that held in Januari. Students in this class were given the lesson on mastering internet especially emailing and browsing some useful website that needed to do assignments from teachers. Students were looked very enthusiastic and occasionally asked to their teacher.

In SMAN 1 Bandarlampung, the media literacy course is more focus on the Information and Communications Technology (ICT) rather than on the mastery of media literacy itself.. According to Lampung Education Institution's data, almost 99 schools have already applied media literacy lesson, even though it is not as a particular course because it's a part of Bahasa Indonesia (Indonesian Language) course. And it's not yet a required course but media literacy is already given to students for one semester in the last year.

The Education Ministry's media literacy program has implemented since 2009 under Bahasa Indonesia (Indonesian) course. Media Literacy is given for the last level or the third class for high school student and only in several weeks per semester in the last semester of every academic year.

Dinas Pendidikan Bandarlampung mentions, school with the school committee ${ }^{1}$ can formulate an appropriate curriculum to the

1. School committee is the group of students' parents to facilitates and enhances the participation of stakeholders in education at school level to participate and to formulate, establish, implement and monitor the implementation of school policy and accountability are focused on quality service to learners and open proportionally. This committee is also facilitates the participation of the stakeholders to participate in school management in accordance with the roles and functions, with regard to planning, implementation and evaluation of school programs in proportion. 
needs, circumstances, and conditions of the school environment.

This is in line with the characteristics of its education standard or Kurikulum Pendidikan ${ }^{2}$ which provides the flexibility for teachers and schools to develop their own units in tune with the students, schools, and environmental circumstances. In the Kurukulum Pendidikan of Bahasa Indonesia, media literacy is taught as one chapter with title variety or journalism language. Its contents are to put forward suggestions to the information content of radio or television news, speaking without a text, reading the literature to distinguish the characteristics of different languages and understand the criticism and essay writing.

Each school is allowed to develop their own course materials. Sekolah Menengah Atas Negeri (SMAN) or State High School 1 Bandarlampung is one of high schools in Bandarlampung city that has implemented media literacy and gives this course as a part of Bahasa Indonesia (Indonesian) lesson. It aims to steer teens in selecting media and mass media products is safe with emphasis on language. This school has been chosen as one of three high schools in Lampung Province that being the pilot project of the implementation of Bahasa Indonesia course that contains media literacy course.

The other two high schools or SMAN in Lampung Province that being the pilot project of the implementation of media literacy course are SMAN 1 Pagelaran in Pringsewu Regency and SMAN 1 Metro. Pringsewu

2. Kurikulum Pendidikan, is an educational operational curriculum that developed and implemented in each educational unit in Indonesia. It is legally mandated by Act No. 20 of 2003 on National Education System and the Government of the Republic of Indonesia Regulation Number 19 Year 2005 on National Education Standards. The preparation of the curriculum by the school started in the academic year of 2007/2008 with reference to the standar isi/Content Standard and the standar kompetensi kelulusan/Graduate Competency Standards for primary and secondary education as published by the National Education Minister Regulation No. 22 respectively in 2006 and No. 23 of 2006, as well as curriculum development guide released by BSNP or Badan Standar Nasional Pendidikan/ National Education Standards Agency.
The selection of these three schools or SMAN is determined by the city education office Bandarlampung. It is because these schools are the public/state schools with the academic achievement level of students' in general are very good compared to other state and private high schools in Lampung Province. The media literacy program in Sekolah Menengah Atas Negeri (SMAN) or State High School 1 Bandarlampung is as a part of Bahasa Indonesia course that lacks the standard requirements of formal media literacy course as defined by the UNESCO.

The UNESCO took the Media Literacy definition from one expert, Ofcom in response to 'a wide-ranging stakeholder consultation in 2004', that the media literacy is ability to access, understand and create communications in a variety of contexts, but the mastery of ICT is only one part of the whole media literacy education. This is as mentioned in UNESCO's Media and Information Literacy Curriculum for teachers outlines of the components that Media Literacy contents are, understand the role and functions of media, understand the conditions under which media and fulfill their functions, critically analyze and evaluate media content, use of media for democratic participation, intercultural dialogue and learning, produce user-generated content and ICT and other media skills (Towards Media and Information Literacy Indicators, Unesco, p. 31).

As the critically analyze and ability to evaluate media content is also important in this curriculum, in generally, the definition of media literacy is defined as the ability to access the media, to understand and to critically evaluate different aspects of the media and media contents and to create communications in a variety of contexts. And media literacy is not only to mastery in ICT like in SMAN1 Bandarlampung.

And W. James Potter in his book, Media Literacy says that the Media Literacy is a perspective that is used actively when, the individual accessing the media in order to interpret the messages conveyed by the media. In SMAN 1 Bandarlampung, this course is only a chapter of Bahasa Indonesia course that mostly about introduction on internet base course such as how to access and use websites as a source to assignments, as well as how to make, use and access blogs, email, as well as how to using email, social media and blogs. The media literacy in this school focuses on ICT course. 
It aims are to improve the students' knowledge about internet and new media and to give them chance to mastering in access useful websites especially school website, social media and blogs.

Sometimes, teacher shows movie in the class to be analyzed by students. For instance, movie about creation of human being, in the discussion session students compare the human creation in religion with science perspective then they present what they have discussed in the group in front of the class, and other group can give suggestions, questions and even critics.

Students also use school website to get the instruction and guidelines of assignments. Other way is movie in the class so students can watch and analysis it in a group of discussion then doing presentation in the class. This chapter is also contains the mastery on using power point software program that usually support other course especially when it is needed for presentation the assignment.

Part of this course is also what they call as elearning, which is teacher post assignment on the official school's website complete with the assignment introduction and rules then the students should post their answers/essays to its website and/or through email to the teacher. In the school area, there is an internet access that can freely accessed by students and teachers.

The lack of this course is mostly about the achievement of mastery the internet by students who don't have laptop and/or internet access at home.The school still implements this ICT course because they believe the internet-base knowledge is needed in this era and young people should have knowledge about internet.

The head of SMAN 1 Bandarlampung gives guidelines to student in access internet and its materials and give student suggestion in using and filtering internet. But teachers cannot do the fully monitoring to students in access internet and parents, participations are needed.

This school ignores the fact that ICT is not about internet only and media literacy is not about mastery on internet or even mastery on ICT. While according to Education Institution in Bandarlampung City, Media Literacy is included the diversity of journalism and communication languages. Even though, The Education Institution (Dinas Pendidikan) in
Bandarlampung City agrees that information flows rapidly every day and people need information to update their knowledge.

Under the diversity in journalism language, students have to criticize the content of the news information on television and radio as well as analyzing the structure of the journalism language in the news on television, radio and online news media. In the part of communication language, students are invited to improve their competence in speaking, reading literature, understand and write a critique of the news media.

The weakness of the implementation of media literacy in Bandarlampung City is because it is given under Bahasa Indonesia course and it is only one chapter that given only in one week. Students have less time to get more detailed lessons about media literacy and less ability to explore its in terms of criticizing the media and media contents as it's mentioned in UNESCO's curriculum of Media and Information Literacy. Other obstacles are internet facility and laptop by students.

In Bandarlampung City, the media literacy education is important. According to the Education Institution official in Bandarlampung City, this is important because by taking media literacy course, students are required to understand the information from variety of media that submitted by the students in the class orally. Students also have to put forward their suggestions on improvements the related information from mainstream media, especially radio and television.

The contents of media literacy for high school students in Bandarlampung City should be included variations of diversity in journalism and communication languages. Students have to criticize the content of the information in the news on television and radio as well as analyzing the structure of the journalism language in the news on television, radio and online news media.

Potter (Baran and Davis, 2003) gives a somewhat different approach in explaining the fundamental ideas of media literacy, namely a continuum, which is:

Not a categorical condition, media literacy needs to be developed by looking at the degree of maturity, media literacy is multidimensional, i.e. the cognitive domain which refers to mental processes and 
thought processes, emotions domain of the dimension of feeling, aesthetic domain refers to the ability to enjoy, understand and appreciate media content from the artistic standpoint, and the moral domain refers the ability to capture the values that underlie a message and the purpose of media literacy is to give us more control to interpret the message.

And, in order to make student as the young people in Bandarlampung can properly choose e good media as information source there is a guideline.

\section{E. SUMMARY}

\section{CONSLUSION}

Media literacy education is the education of practical skills application. Media literacy education has more value, because it puts students as education subjects. This makes the development of emotions thought patterns, character, and behavior of students are more controlled. Because, the students provided with the ability to select and interpret media messages, so that students are no longer as an imitator media and more critics with media contents.

It shows that media literacy education include not only cognitive skills but also build a power analysis, to make students able to respond to what happens outside them.

In UNESCO's Media and Information Literacy Curriculum, Media Literacy contents are, understand the role and functions of media, understand the conditions under which media and fulfill their functions, critically analyze and evaluate media content, use of media for democratic participation, intercultural dialogue and learning, produce usergenerated content and ICT and other media skills (Towards Media and Information Literacy Indicators, Unesco, p. 31).

As the critically analyze and ability to evaluate media content is also important in this curriculum, in generally, the definition of media literacy is defined as the ability to access the media, to understand and to critically evaluate different aspects of the media and media contents and to create communications in a variety of contexts.

But in SMAN 1 Bandarlampung, media literacy more focuses on ICT and given to students in last level as a chapter of Bahasa Indonesia course.

In terms of urgency, Media Literacy Learning has a great opportunity to develop, given the rapid development of the media are not followed by a skill in taking it.

It must be admitted that not all schools ready to implement media literacy education, one of which SMAN 1 Bandarlampung. This is due to lack of availability of specialist teachers to deliver media literacy media literacy education.

\section{RECOMMENDATIONS}

1. Although every school is given the discretion to implement media literacy education in accordance with the conditions, the ability of the teacher and supporting tools, but SMAN 1 Bandarlampung may seek to issue a media literacy lesson of Indonesian language study to stand alone.

2. The content of media literacy course in SMAN 1 Bandarlampung should be in a line with the standard curriculum of media literacy course by UNESCO that emphasize the media awareness.

3. In Bandarlampung, the application of Media Literacy learning can be hampered if there is no synergy between the school and the education office. Therefore, commitment is needed from education office and school.

4. Bandarlampung City of Education Institution/office has to prepare and add teachers for high schools with specialist competence in media literacy by providing education and training to teachers.

5. Bandarlampung city education office should develop a curriculum for media literacy lessons that are tailored to the curriculum of the UNESCO. 


\section{References}

Act of Republic of Indonesia Number 20 Year 2003. Retrieved on January 12, 2020 from http://www.inherent-

dikti.net/files/sisdiknas.pdf

Anggraeni, Filia Dina. (2002). Pembelajaran Melek Media Pada Siswa SD (Pendekatan Teori Belajar Humanistik). Fakultas Kedokteran Universitas Sumatera Utara

Baran and Davis. (2003). Media \& Society: The Role of Media in the Social World. p.301

Buku Putih Pers: Antara Idealisme dan Euforia. (2002). Bandarlampung: PWI Cabang Lampung

Considine, David; Horton, Julie and Moorman, Gary. (2009). Teaching and Reading the Millenial Generation Through Media Literacy. p.471-481. International Reading Association

Kovach, Bill and Rosenstiel, Tom. (2007). Elements of Journalism.

Moeller, Susan; Joseph, Ammu; Lau, Jesus and Carbo, Toni. (2001). Towards Media and Information Literacy Indicators (Background Document for the Expert Meeting). Paris: UNESCO

Pengajaran Pendidikan Media Melalui Sekolah Dasar. Retrieved on December 10, 2019 from http://sadidadalila.wordpress.com/2010/03/ 20/media-literasi/

Potter, W. Media literacy. (2001). Los Angeles: SAGE Publications,

Rogow, Faith. (2011). Inquiring Minds Want to Know: Media Literacy Education for Young Children. Library Media Connection 